\title{
Tax reform of 2019 in Uzbekistan
}

\author{
Yuldasheva Umida Asanaliyevna ${ }^{1}$ \\ ${ }^{1}$ Docent at the "International Finance Credit" Department of Tashkent Financial institute \\ Email: umida_yu@mail.ru
}

\begin{abstract}
This article discusses how the tax reforms affect the budget and business atmosphere in Uzbekistan. The country has already implemented several tax methods but few of them have made the economy flourish. Yet, recent changes differ from previous ones with these reforms reflecting the experiences of those countries whose economy is highly affected by the tax in a positive way. In order to dramatically decrease the tax burden on companies and individuals, the number of direct taxes has been cut hoping to open the hidden economy in the country. However, the meaning of direct taxes has been moved into indirect ones such as VAT. Below we will do our best to analyze the outcomes of the previous tax reforms and offer some taxation mechanisms which can help the economy of the country.
\end{abstract}

Key words: tax, tax burden, tax reforms, government budget, private companies, VAT, excise tax, tax policy.

\section{INTRODUCTION}

Only very few developing countries have managed to establish their tax systems in such a way as to achieve an appropriate level of revenue and to keep tax-generated misallocations within tight bounds (one such example is the city state of Singapore). In most other countries, neither has it been possible to ensure the financing of public expenditure nor have the tax systems operated in conformity with economic policy objectives such as growth and combatting poverty. ${ }^{1}$

The most striking evidence of the need for reform comes from the revenue side: estimates made by the World Bank for the period 1975-1985 showed that in industrial countries the average taxation ratio as a proportion of gross domestic product lay between $29 \%$ and $32 \%$ whereas the corresponding range for developing countries in the mediumincome category was from $17 \%$ to $22 \%$. The average taxation ratio in the poorest countries lies between $13 \%$ and $16 \%$. The proportions are relatively high in the Middle East and North Africa because of the royalties and other levies raised from oil exports, which are classed as taxation. In sub-Saharan Africa, Latin America, the Caribbean and in East Asia, the corresponding values lie between $14 \%$ and $18 \%$, whilst they are in the range $10 \%-14 \%$ in South-East Asia. ${ }^{2}$

Last year Uzbekistan has experienced many changes and reforms in many spheres, and one of them could be undoubtedly those of taxation system. The tax reform was mainly adapted for three essential issues. Now I am going to pay attention to these problems and what solutions were to be made in the start of 2019.

1. High rate of taxes on the payroll fund.

Those taxes were not helping employment to increase but encouraging economy under the shadow.

In 2019 taxes on payroll decreased dramatically:

$-8 \%$ of the insurance deducted from the salary to the Pension Fund was cancelled;

- the "flat" scale of $12 \%$ of the income tax was introduced instead of the progressive type of $22.5 \%$ of the highest tax rate;

$-25 \%$ of the total taxation and $15 \%$ of the unified social payment are set at $12 \%$;

2. Uneven distribution of the tax burden.

First of all, we are talking about a huge difference between simplified and general taxation procedures (ie, small and large businesses). When a company moves from one mode to another, the tax burden may increase several times. This impedes business growth and drastically reduces the competitiveness of national producers. In this regard, it is planned to sharply reduce the tax burden and simplify the general rules of taxation, including:

- mandatory deductions to state-owned funds for large enterprises were abolished ( $3.2 \%$ of revenues);

- the corporate income tax rate was reduced from $14 \%$ to $12 \%$ (for commercial banks - from $22 \%$ to $20 \%$, for cellular companies - from $14 \%$ to $20 \%$, and the tax paid at a certain level of profitability. abolished, increased from $14 \%$ to $20 \%$ for cement and polyethylene granules manufacturers);

- the dividend tax was reduced from $10 \%$ to $5 \%$;

- the property tax rate of legal entities decreased from $5 \%$ to $2 \%$, and the requirement for water use by all legal entities was introduced;

3. Availability of turnover tax in Uzbekistan, contrary to international practice.

That is, it is not the value-added tax, but the income tax, which includes all costs, not profit. This would include deductions from state-owned funds for the general taxation system, single tax payment for small businesses, businesses, and catering.

\footnotetext{
${ }^{1}$ Cf. S. Acharya: India's Fiscal Policy, in: R.E.B. Lucas, C.F. Papanek (eds.): The Indian Economy. Recent Development and Future Prospects, Boulder, London 1988, pp. 301 ft.; Schwere Rezession in Peru. Pl\&ne Carlos Bolol3as fur eine Fiskalreform, in: Neue Zurcher Zeitung, No. 53, 6 March 1991; K.W. Menck: Mobiiisierung interner Ressourcen durch die Steuerpolitik in Entwicklungsl\&ndern -eine Fallstudie fur ein fortgeschrittenes Land: Singapur, HWWA-Report No. 85, Hamburg 1990.

2 Cf. World Bank: World Development Report 1988, Washington, D.C., 1988.
} 
Income tax, as well as disruptions in the value-added tax chain (where VAT is actually a reflection of income tax), are affecting very negatively on the distribution of social labor, the formation of a long chain for added value creation. The longer the chain, the higher the tax burden, the more double and triple the taxation. Under these conditions, it was impossible to create a complete production cycle, from raw materials to finished products with high-added value. Considering all of them, following steps were taken in this way:

- abolition of deductions to the state funds for enterprises of the general taxation system;

-reducing the tax burden on enterprises of the general taxation system, thus encouraging small businesses to enter the system;

- transfer of enterprises with gross income more than 1 billion soums at the end of the year, or exceeding the established threshold for the year;

However, all is wonderful and we cannot say it is going to work very well. There are problems with the implementation of reforms, and they are not small.

\section{THE BIGGEST MISTAKE IN THE IMPLEMENTATION OF REFORMS.}

The first problems of the reforms can be seen in the rate of taxes. To be more precise, VAT rate was appointed at 20 percent. Yet, the first version of the tax reform concept envisaged a rate of $12 \%$ of this tax. Firstly, the authors of tax concept aimed for the rate of neighbor countries, Kyrgyzstan and Kazakhstan. Secondly and more importantly, it might enable small enterprises to move to common taxation system more easily.

Yet, in fact:

- the legalization of business and the transition to a common taxation system were less than expected after reforms. The business has been active in avoiding VAT, including in the form of business grinding, hiding revenue, reregistration as a new legal entity;

- some types of local goods and services have been less competitive than neighboring countries;

- as the tax base decreases, budget revenues may decline.

Many of the problems we faced last year in transitioning to the new system of taxation were due to the reluctance to reduce the VAT rate.

Other issues, which were observed during the tax reform.

Unfortunately, some of the tasks set out in the June 2018 presidential decree were somehow eroded.

1. A new version of the Tax Code were not developed. But it took half a year to do that. The changes to the code in December 2019 would not solve many problems with the new tax system. This was a big blow to the reforms.

2. The problem with VAT on agricultural products produced by themselves was not solved at the beginning of the year. The problem was that agribusinesses did not pay VAT, and consequently, catering and trading companies that buy and process their products could not be considered as members of the value chain. As a result, the tax burden on these businesses would increase. In turn, there were good options to solve this problem, but they were ignored.

It is true that Article 208 of the Old Tax Code in 2019 stated that some of the foodstuffs produced in the Republic of Uzbekistan were exempt from VAT and their list was approved by the Cabinet of Ministers. But where and why should this list be decided by the Cabinet, rather than by the Code? Also, what should non-food processors, such as textile companies, do? For them, the problem was not solved at all.

3. The plan for simplification of VAT and income tax calculation and payment was not implemented. The registration of these taxes remained difficult for both taxpayers and tax authorities during the previous year. This hindered successful tax reform.

4. Tax preferences were not optimized. Many tax incentives were ineffective and harmful: they kill competition (some are privileged, some don't) and the state budget was reducing revenues. It is no coincidence that the President reiterated the issue of optimization in his December 29, 2018 statement: "At the expense of reducing the tax burden, it is necessary to introduce a fair tax system for all people, and gradually eliminate the tax benefits."

5. Contrary to the concept of tax reform (with a single tax rate of $4 \%$ ), different tax rates for different sectors of the economy were set ("Forecast of main macroeconomic indicators and parameters of the State Budget of the Republic of Uzbekistan for 2019). and the budget budget for 2020-2021 ". In particular, catering in cities with a population of over 100,000 people pay a single tax at the rate of $8 \%$.

6. A number of important provisions of tax legislation were approved without any discussion. They were:

-simplified VAT system;

- introduction of excise tax on mobile services, increase of excise tax on cigarettes produced in the territory of the Republic of Uzbekistan;

- Introduction of a single tax payment to individual entrepreneurs with a turnover of more than 100 million, but less than 1 billion. Why was this category of entrepreneurs sole tax payers? However, one of the main objectives of the reform was to reduce the tax on turnover (in this case it expanded).

Now let's turn to numbers in order to see what kind of results have been achieved. According to operative data, in 2019 the revenues of the state budget and state trust funds will reach 137 trillion. soums (26.1\% of GDP), which is $27 \%$ more than in 2018 (in 2018, revenues amounted to 108 trillion soums or $26.5 \%$ of GDP). Instructions on the 
implementation of the state budget execution software, known for its achievements in 2019, revenues amounted to 112.1 trillion. Production of soums increased by 1.4 times compared to 2018 (79.1 trillion soums). At the same time, the revenues of the state budget for GDP development increased from $19.4 \%$ to $21.4 \%$ or $2 \%$ of GDP.

State Targeted Funds, 29 trillion soums in 2018 (7.1\% of GDP preparation) The process of creating 24.9 trillion soums in 2019 (4.8\% of GDP). At the same time, the income is related to the income, which is added to the tax-related people.

According to operative data, in 2019 the revenues of the state budget and state trust funds will reach 137 trillion. soums (26.1\% of GDP), which is $27 \%$ more than in 2018 (in 2018, revenues amounted to 108 trillion soums or $26.5 \%$ of GDP).

Instructions on the implementation of the state budget execution software, known for its achievements in 2019, revenues amounted to 112.1 trillion. Production of soums increased by 1.4 times compared to 2018 (79.1 trillion soums). At the same time, the revenues of the state budget for GDP development increased from $19.4 \%$ to $21.4 \%$ or $2 \%$ of GDP.

State Targeted Funds, 29 trillion soums in 2018 (7.1\% of GDP preparation) The process of creating 24.9 trillion soums in 2019 (4.8\% of GDP). At the same time, the income is related to the income, which is added to the tax-related people.

According to operative data, in 2019 the revenues of the state budget and state trust funds will reach 137 trillion. soums (26.1\% of GDP), which is $27 \%$ more than in 2018 (in 2018, revenues amounted to 108 trillion soums or $26.5 \%$ of GDP).

Instructions on the implementation of the state budget execution software, known for its achievements in 2019, revenues amounted to 112.1 trillion. Production of soums increased by 1.4 times compared to 2018 (79.1 trillion soums). At the same time, the revenues of the state budget for GDP development increased from $19.4 \%$ to $21.4 \%$ or $2 \%$ of GDP.

State Targeted Funds, 29 trillion soums in 2018 (7.1\% of GDP preparation) The process of creating 24.9 trillion soums in 2019 (4.8\% of GDP). At the same time, the income is related to the income, which is added to the tax-related people. 46.4 trillion. As in previous years, indirect taxes (VAT, excise tax and customs duties) accounted for the main source of income in the amount of UZS. Revenues from these sources increased by 13 percent compared to last year.

Real VAT revenues in 2019 will reach 3.2 trillion in 2019. The amount of refunded VAT increased by 2 times compared to the corresponding figure in 2018 (in 2018, the refund of VAT was reflected in the budget expenditures and amounted to 1.5 trillion soums).

Revenues from direct taxes - 31.7 trillion. soums (more than twice as much as last year), and 19.7 trillion soums in resource taxes and property taxes. soums (increased by 1.5 times). Value added tax. The main share of revenues from indirect taxes falls on value added tax. The amount of VAT calculated or levied by the tax authorities in the country is 23.7 trillion soums. soums, while the amount of import duties is 13.4 trillion soums. soums or 37.1 trillion soums in total. soums.

In 2019, the reform of the tax system began, which provides for significant changes in tax policy and improvement of tax administration. The large-scale reform, which will take place in the short term, has covered all tax instruments. For example, a limit was imposed on the payment of value added tax on the basis of turnover, rather than on the basis of the number of employees. Measures have also been taken to significantly expand the tax base by increasing the number of taxpayers and abolishing tax and customs benefits.

The number of VAT payers increased from 6.7 thousand to 82 thousand (as of December 1). In 2019, 6.7 trillion. UZS or $29 \%$ of this tax revenue collected by the tax authorities falls on the share of new VAT payers.

In 2018, according to international experts' assessment of the efficiency of the Uzbek tax system, the low S-efficiency coefficient for VAT (S-efficiency = VAT revenue / gross consumption minus VAT revenue) indicates that the potential for VAT collection has not been fully used. Many companies with significant turnovers pay a single tax and are not subject to VAT. In this regard, the following recommendations were made:

Introduce a turnover-based limit for a single tax payment in order to expand the overall base of VAT payers; Improving the system of accounting for the amount of VAT on the purchase of resources (granting the right to account for VAT on long-term assets, refund of all excess VAT amounts (negative VAT amount) incurred in the purchase of resources).

Compared to the main regions of the world and the corresponding countries in the region, the efficiency and collection of VAT in Uzbekistan was one of the lowest. VAT efficiency was low due to a number of interrelated factors. The narrow tax base, widespread use of tax incentives, deficiencies in revenue management, low taxpayers' ability to meet their obligations through informal economic activities, and understated income led to more tax losses than potential. Measures have been taken to abolish some tax and customs benefits, as well as to reduce the VAT rate from $20 \%$ to $15 \%$.

As a result, the efficiency of VAT in 2019 was estimated at 0.35 , and in 2020 is expected to be 0.45 (in 2020 , the S-efficiency is expected to be 0.6 ).

The measures taken (reduction of the VAT rate, abolition of tax exemptions and further increase in the number of taxpayers) will affect the state budget revenues in the coming years. In particular, it is estimated that in 2020, revenues from this tax will reach 44.2 trillion. UZS (taking into account the refunds of this tax in the amount of 3.4 trillion UZS) or an increase of $30 \%$ compared to the current year. The expected increase in sales of goods (services), the abolition of benefits, as well as the introduction of new forms and methods of tax administration in the form of electronic invoices and analysis of amounts accounted for by taxpayers will be key factors in revenue growth.

However, the validity of tax and customs benefits provided until January 1, 2020 will be abolished. It is also planned to further optimize the benefits provided: after January 1, 2020, value added tax benefits will be provided only by the Tax 
Code of the Republic of Uzbekistan. According to international practice, a large number of benefits and exceptions to the general tax regime violate the principle of fairness to participants in economic activities who do not enjoy tax benefits, because the preferential treatment provided to certain taxpayers inevitably imposes an additional tax burden on others. The quality of products is declining due to insufficient competition in existing markets. While some businesses are dependent, others are highly profitable.

In many cases, benefits are provided to protect low-income households. However, an analysis of practice in many countries shows the opposite. Although prices fall as a result of incentives, in most cases, the consumption of basic goods, goods and services by high-income households increases. They are the ones who benefit most from the benefits provided. Consequently, there is an increase in regression, not progression, of the tax deducted from the tax base.

At the same time, as a result of VAT exemptions, producers are expected to adjust their prices to increase or decrease VAT rates, thereby reducing the tax burden on end consumers. However, studies in many countries show the opposite. According to their results, in most cases, prices did not fall, and even if they fell, they remained at the same level throughout the year.

IMF research shows that the benefits undermine VAT neutrality and the original purpose of production decisions. Enterprises that produce VAT-exempt products will be encouraged to become self-sufficient and have vertical integration. Privileges can hurt local producers because they encourage the purchase of resources from abroad: the obligation to pay the incoming tax is imposed on local producers, and similar imported products are exempted from it. Another complication is that businesses can produce taxable and non-taxable products, which requires the application of complex VAT allocation rules on purchases to determine the amount of tax to be taken into account.

In 2019, the amount of VAT refund will reach 3.2 trillion. soums or $8.7 \%$ of total VAT revenues (in $2018-1.5$ trillion soums or $5.4 \%$ ). The increase in the number of VAT payers has led to an increase in the amount of refunds (exporters buy goods (services) from tax counterparties).

At the same time, the ratio of tax refunds to the amount of VAT collected (8.7\%) is relatively low in the country compared to other countries (in other countries this figure averages $15-20 \%$, and in some countries more than $40 \%$ ).

Currently, the amount of VAT can be refunded only to exporters. Other taxpayers whose tax credits exceed their tax liabilities are required to make the difference in future periods. However, the refund of the VAT amount is of fundamental importance for the operation of the VAT. Measures are being taken to allow all companies to recover their VAT amounts, but additional steps will need to be taken to improve the procedures involved.

According to the Law of the Republic of Uzbekistan "On Amendments and Addenda to the Tax Code of the Republic of Uzbekistan" dated December 30, 2019 No. ZRU-599, from July 1, 2020, the amount of VAT generated as a result of excess of VAT.

At the same time, from 2020, it is planned to fully account for VAT on purchased buildings and fixed assets used for the production of taxable products.

From January 1, 2019, VAT payers were given the right to record VAT paid on the purchase of fixed assets for 12 months, and on unfinished objects and intangible assets for 36 months in equal shares. As of January 1, 2019, the amount of value added tax is reflected in the value of long-term assets purchased.

"Social" benefits, which have a significant negative impact on income productivity, provide insignificant protection and benefit to low-income groups. A more effective redistribution policy would be to impose a full rate of VAT on them and use the proceeds to improve the situation of the poor.

Revenues from value-added tax on imports of goods increased by 1.5 times compared to last year and amounted to 13.4 trillion. soums. In the 4 th quarter of 2019 , due to the abolition of benefits, additional revenues will reach 0.9 trillion. soums, including $237 \mathrm{bln}$. soums due to timber. soums, at the expense of the automotive industry - $270 \mathrm{bln}$. soums and others.

The introduction of a single personal income tax rate is associated with a reduction in the single social payment rate and the amount of contributions to personal pension savings accounts (PPAs), as well as the use of force by certain categories of taxpayers (judges, prosecutors, customs officials and others). employees) to expand the coverage of these taxpayers through the abolition of benefits, to increase revenues from this tax to 6.4 trillion. 12.7 trillion soums soums, which is almost twice as much. Consequently, in terms of budget revenues, these revenues amounted to 11.4 trillion. soums.

Compared to the previous year, the following were the main factors in the increase in state budget revenues: Abolition of benefits, including for employees of the prosecutor's office, law enforcement agencies, the judiciary and law enforcement agencies (about 1 trillion soums);

Reduction of the norm of allocations to the SPC from $2 \%$ to $0.1 \%$ (about 1.9 trillion soums).

The increase in personal income tax revenues is also due to the rapid growth of wages in the private sector and the legalization of the number of employees.

Thus, despite the reduction of the tax burden on the Wage Fund, the amount of personal income tax revenues has increased. Thus, according to preliminary estimates, the share of GDP revenues increased from 2.15\% of GDP in 2010 to $2.42 \%$ in 2019 .

In 2019, fixed tax revenues will reach $\$ 659$ billion. UZS or $36 \%$ less than in 2018 , which is due to the reduction of rates by an average of $30 \%$, the introduction of a single tax payment criterion, as well as the reduction of activities that can be carried out by individual entrepreneurs.

According to the results of 2019, the amount of income tax will be 16.4 trillion. soums, which is 5 times more than in 2018 (in 2018 - 3.3 trillion soums). Increase in profits of large companies (more than 6 trillion soums in 2019) 
due to the transition of the republic's mining companies to the new tax system, as well as the abolition of mandatory deductions of $3.2 \%$ of turnover, reduction of the single social payment for non-state taxpayers (25\% to $12 \%$ ), the increase in the number of taxpayers was the main factor in the increase in income tax revenues.

Revenues from new income taxpayers (41.2 thousand enterprises) amounted to 1.6 trillion soums. soums, or about $10 \%$ of the total revenue.

Simultaneously with the abolition of the VAT for cement plants, mobile operators and polyethylene granule manufacturers, the introduction of an increased rate of $20 \%$ instead of the basic rate of $12 \%$ in 2019 will provide an additional 170 billion. soums. In 2018, 1.5 trillion rubles will be spent from these taxpayers. soums of additional income tax. In 2020, revenues from this source will reach 22 trillion. soums. The expansion of the tax base for this tax is due to the reduction of the single social payment rate for state-owned enterprises from $25 \%$ to $12 \%$, as well as the reduction of the tax rate for subsoil use for precious metals.

At the same time, the income tax rate was increased from $12 \%$ to $15 \%$ in order to partially compensate for budget losses from the reduction of the value added tax rate. It is estimated that the losses from the reduction of the value added tax rate will be about 11 trillion. UZS, additional income tax revenues will amount to 2 trillion soums. soums.

The increase in the income tax rate is also explained by the fact that income in the form of wages is currently at the rate of $24 \%$ (12\% - personal income tax and $12 \%$ - a single social payment), and the income of the founder of a legal entity $-16.4 \%$ (profit income in the form of tax and dividends are taxed at the source of payment). By itself, it is more profitable for the owner to receive dividends than to receive wages.

At the same time, an increase in the income tax rate to $15 \%$ will increase the total tax burden to $19.3 \%$, which is closer to the tax burden on income in the form of wages.

The reduction of the tax rate on dividend income from $10 \%$ to $5 \%$ (for both legal entities and individuals) in addition to income paid to non-residents did not lead to a decrease in revenues from this source. In 2018, revenues will reach 616.1 billion. In 2019, they will amount to 838.7 billion soums. soums.

In order to introduce the principle of mandatory calculation and payment of land tax and property tax, as well as tax on the use of water resources, from January 1, 2019, all businesses, including legal entities with a turnover (income) of up to 1 billion soums, began to pay these taxes. At the same time, in 2019 , the property tax on legal entities will be reduced from $5 \%$ to $2 \%$.

Reducing the corporate tax rate from $5 \%$ to $2 \%$ will increase revenues by $\$ 1.9$ trillion. sum 1 trln. soums. As a result of the increase in the tax base ( 7 times) due to the coverage of all business entities with the payment of property tax, in 2019 revenues from this tax will reach 1.6 trillion. soums. At the same time, revenues from new taxpayers $(55,705$ enterprises) for 2019 will amount to about 629 billion. soums or one third of the total revenue.

The number of land tax payers from legal entities increased by 5.8 times compared to 2018 and amounted to 74,707 enterprises, the number of taxpayers for the use of water resources increased by 14.8 times and amounted to 50,898 enterprises. Accordingly, for 2019, revenues from land tax from legal entities increased by 298.4 billion soums due to the expansion of the range of taxpayers (for reference: taxable land increased by 388.6 thousand hectares and amounted to 888.6 thousand hectares), water Taxes on the use of natural resources increased by 33.5 billion soums.

At the same time, due to the indexation of the rates of land tax (1.2 times) and the tax on the use of water resources (1.2 times), additional revenues from land tax in 2019 will be 133.3 billion soums. soums, 26.9 bln. soums on taxes for the use of water resources. soums.

$\$ 100$ billion in taxes on water use Additional revenues in the amount of UZS (according to estimates) were provided by increasing tax rates for industrial enterprises ( 3 times) and for enterprises specializing in vehicle washing (10 times) from October 1, 2018.

Revenues from subsoil use taxes in 2019 will reach 4.2 trillion. soums and amounted to 12.6 trillion soums. soums:

- $\quad$ Rising prices for precious and non-ferrous metals, changes in tax procedures and exchange rates;

- Changes in tariffs for natural gas produced within the system of Uzbekneftegaz;

- Calculation and payment of taxes not less than fixed rates for certain types of minerals (in particular, rock (edible) salt, limestone for production of cement, limestone, dolomite, marble slabs, raw bricks, construction sand, etc.) order setting.

\section{CONCLUSION}

Revenues from the single land tax in 2019 will amount to 273.1 billion. soums, of which about 40 bln. soums additional revenues for agricultural enterprises engaged in fruit and vegetable production due to the experience of introducing the calculation of the single land tax for lands engaged in fruit and vegetable production on the basis of the base tax rate and score-quality, taking into account the quality of land. 


\section{REFERENCES}

1. Cf. S. Acharya: India's Fiscal Policy, in: R.E.B. Lucas, C.F. Papanek (eds.): The Indian Economy. Recent Development and Future Prospects, Boulder, London 1988, pp. 301 ft.; Schwere Rezession in Peru. Pl\&ne Carlos Bolol3as fur eine Fiskalreform, in: Neue Zurcher Zeitung, No. 53, 6 March 1991; K.W. Menck: Mobiiisierung interner Ressourcen durch die Steuerpolitik in Entwicklungsl\&ndern -eine Fallstudie fur ein fortgeschrittenes Land: Singapur, HWWA-Report No. 85, Hamburg 1990.

2. Cf. World Bank: World Development Report 1988, Washington, D.C., 1988. 